\title{
Metallic and nonmetallic minerals in China
}

\begin{abstract}
So far, 168 mineral commodities have been discovered in China. Of these, 151 commodities have been explored and over 20 have reserves which rank among the richest in the world. Owing to the diversity of geological settings for mineralisation in China, there is great potential for ore prospecting. There are five large metallogenic domains and five metallogenic provinces. The Proterozoic, the Hercynian and the Yanshanian were the most active periods for metallogenesis and in general, the trend of endogenic ore formation was from mantlederived to crust-derived deposits.
\end{abstract}

\section{An outline of the resources}

China is rich in mineral resources. After much work, especially large-scale geological exploration conducted since the founding of the People's Republic of China (1949), 168 mineral commodities have been discovered up to the end of 1993. Exploration has covered 151 commodities, including five types of energy resource, 56 metallic minerals, 81 nonmetallic minerals, plus groundwater, mineral water and carbon dioxide gas. The total value of potential reserves places China third in the world, and able to meet most of the mineral demands of national economic growth. Various deposits are among the richest in the world, including rare earths, Ta, Nb, Co, V, W, Sn, $\mathrm{Mo}, \mathrm{Sb}, \mathrm{Be}, \mathrm{Li}$, coal, mirabilite, magnesite, barite, fluorite, bentonite, fireclay, asbestos, talc, gypsum, graphite, wollastonite, diatomaceous earth, and building stone. On the other hand, the country is lacking in chromite, platinoid, potash salt and diamond. Ore deposits and mineral occurrences have been discovered in about 200 thousand localities, among which, 20 thousand ore deposits have been investigated in detail. There are 87 supergiant deposits. As shown in Figures 1 and 2, minerals are concentrated in the central and eastern parts of the country. This is because there has been less work in the west where there is great potential for more discovery.

In order to meet the needs of national economic growth, the development and utilisation of mineral resources have been rapidly increased. By the end of 1993, 130 commodities had been exploited,

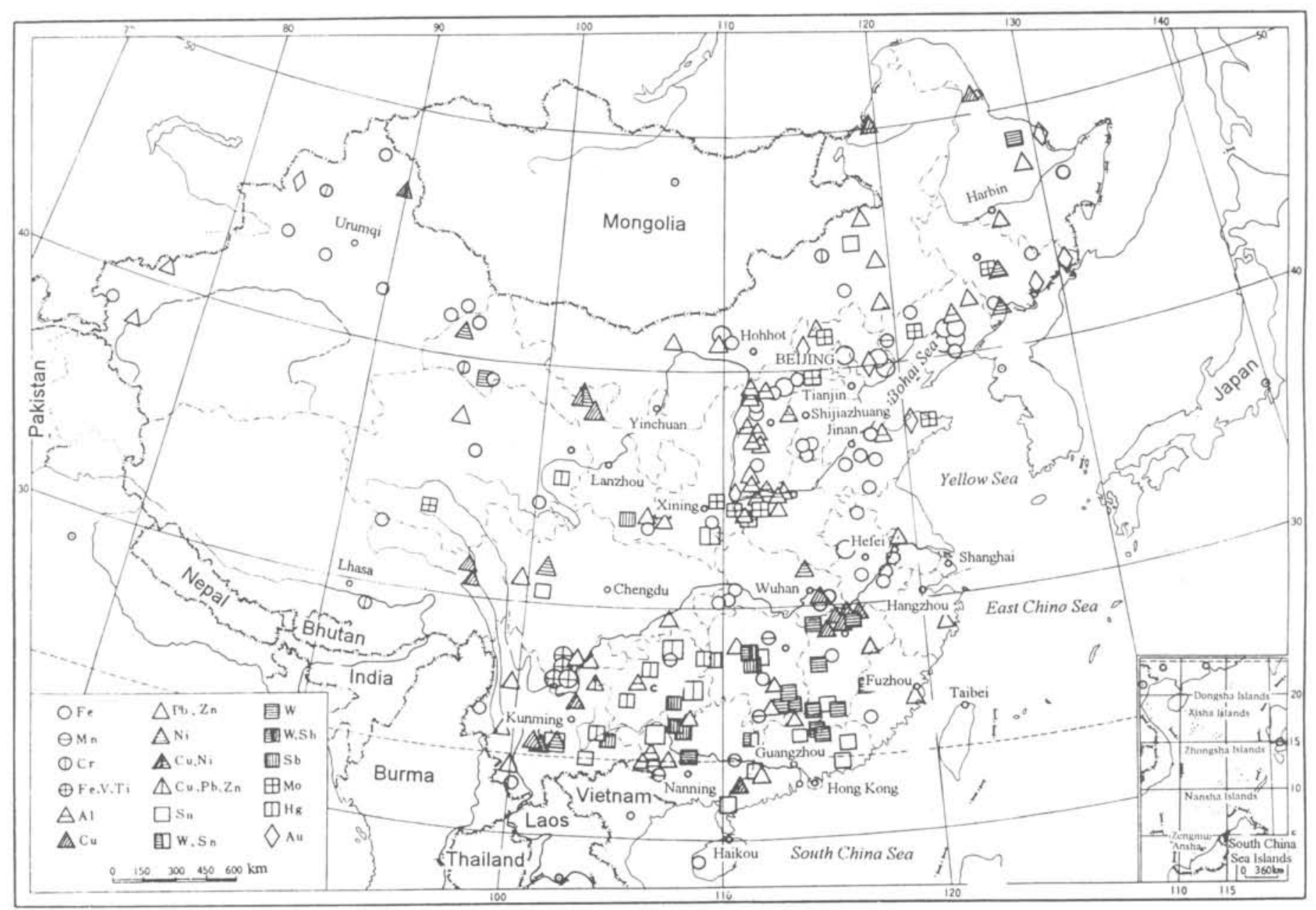

Figure 1 Sketch map showing the distribution of the chief metallic mineral resources of China. 


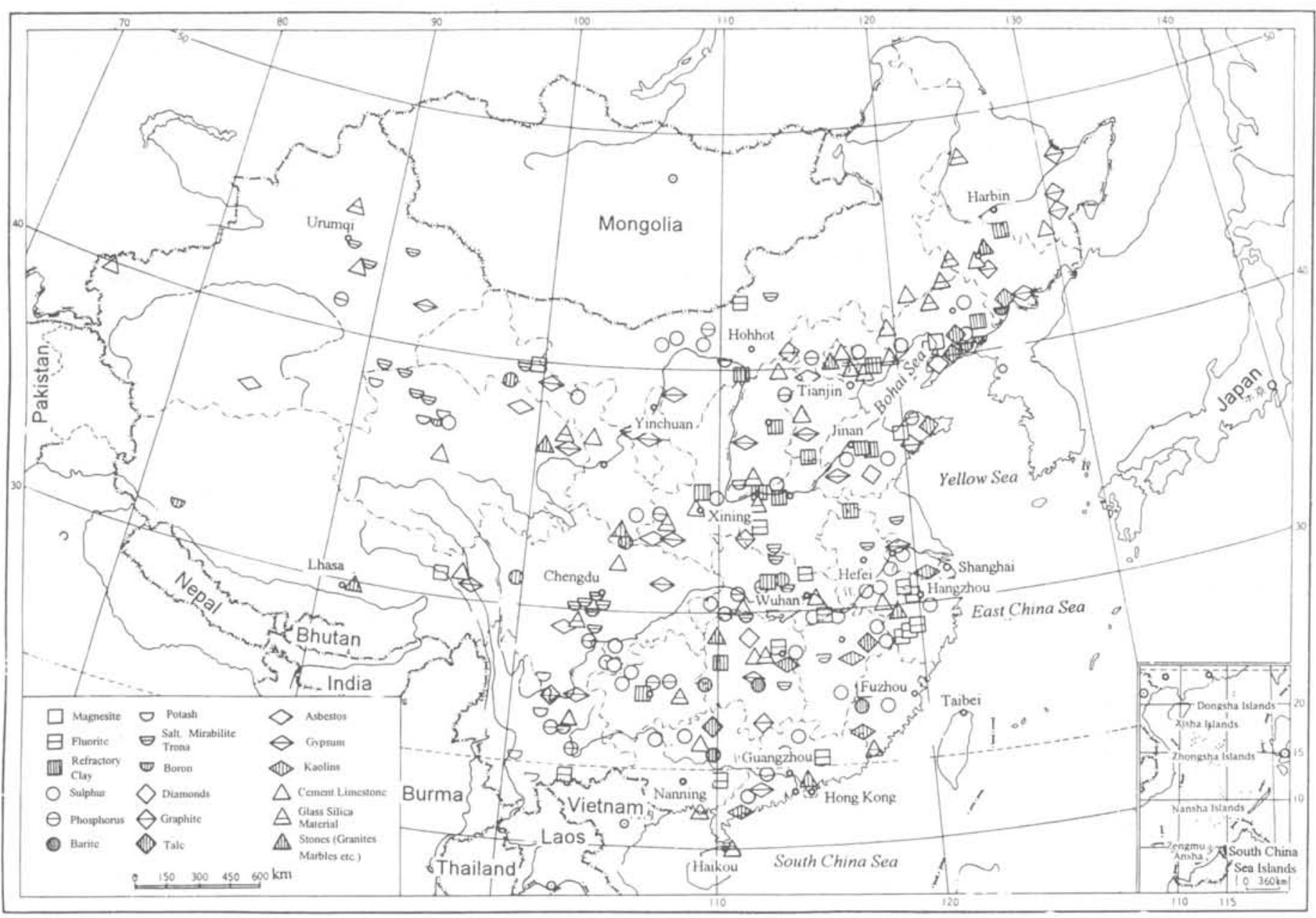

Figure 2 Sketch map showing the distribution of the chief nonmetallic mineral resources of China.

and the total output of ore reached 6.9 billion tonnes. Over nine thousand state-run and over 260 thousand township collective and individual mines had been established which, for the most part can satisfy the domestic demands for mineral products. There is surplus production of some minerals, such as W, Sn, Sb, Mo, Nb, rare earths, coal, magnesite, talc, fluorite, barite, graphite, and building stones, which are exported, while others, such as $\mathrm{Cu}, \mathrm{Fe}, \mathrm{Cr}$, potash salt and diamond, have to be imported to some extent.

\section{Geological setting}

The older, Precambrian land masses have experienced multicyclic tectonics and have been separated, fragmented and reworked by latetectonic magmatism. So, those Precambrian ore deposits, such as infiltration high-grade iron deposits, greenstone Au deposits, conglomerate $\mathrm{Au}$ and $\mathrm{U}$ deposits, and volcano-sedimentary $\mathrm{Pb}-\mathrm{Zn}$ deposits found in stable platforms in the other parts of the world, are less developed in China. However, a number of supergiant deposits were formed, for instance, the Bayan Obo Fe-rare earth deposits in the Inner Mongolia Autonomous Region, the Wengquangou $\mathrm{Fe}-\mathrm{B}-\mathrm{U}$ deposits in Liaoning Province the magnesite deposits in Liaoning Province, the talc deposits in Shandong Province and the Jinchuan $\mathrm{Cu}-\mathrm{Ni}$ deposits in Gansu Province. It should be noted, on the other hand, that intensive Yanshanian tectonic-magmatic-metallogenic activity took place in the circum-Pacific tectonic belt, resulting in the formation of some large-size granitoid-related $\mathrm{W}, \mathrm{Sn}, \mathrm{Bi}$, $\mathrm{Mo}, \mathrm{Sb}, \mathrm{Hg}, \mathrm{Au}$ and rare earth deposits. This part of the country is enriched in these minerals and also contains some of the most significant geochemical anomalies for W, Sn, Mo and Sb in the world. At the same time there is also a series of nonmetallic deposits related to Mesozoic volcanic rock and some large-sized $\mathrm{U}$ deposits in the Mesozoic granites and volcanic rocks of the region. On the QinghaiTibet Plateau in the western part of China, there is a large number of salt lakes and hot springs which produce $\mathrm{K}, \mathrm{B}, \mathrm{Li}, \mathrm{Cr}$, mirabilite, gypsum and rock salt at the large- or even super-large-scales. In both young and old sedimentary basins there are various kinds of sedimentary mineral, for instance, phosphorite confined to the Sinian-Cambrian System and bauxite confined to the Carboniferous-Permian System.

Most of the mineral occurrences are concentrated in certain places, for instance, $\mathrm{Fe}$ deposits are distributed mainly in Liaoning, Hebei and Sichuan provinces; chromite deposits in the Tibet Autonomous Region and the Xinjiang Uygur Autonomous Region; $\mathrm{Cu}$ deposits in the middle-lower reaches of the Yangtze River and eastern Tibet; $\mathrm{Au}$ deposits in eastern Shandong, north-eastern Henan, south-western Shaanxi, south-eastern Guizhou and along the boundary of Heilongjiang; phosphorite in Yunnan, Guizhou, Sichuan and Hubei; bauxite in Henan, Guizhou and Guangxi; W, Sn and $\mathrm{Sb}$ deposits in Jiangxi, Hunan, Guangdong and Guangxi; Ni deposits in Gansu and Xinjiang; and Mo deposits in Shaanxi and Henan. In the eastern part of the country, multicyclic tectonic-magmatic-metallogenic processes, have resulted in metallogenic provinces (or belts) consisting of ore deposits formed at different times, and with different geneses and associations.

Regarding future prospectivity, the multiphase tectonic-magmatic-sedimentary-metallogenic history and favourable ore-forming environments give China a high mineral potential both on- and offshore. In addition, although a great deal of geological survey has been done in eastern China, the surveyed depths are generally in the $300-400 \mathrm{~m}$ range. Therefore there is much potential in the less- 
investigated west and in the deeper parts, and in the peripheries, of the exploited mining areas.

\section{Features of metallogenesis in China}

\section{Metallogenic domains}

The ore-forming processes in China stem from the lithospheric evolution of the country which included frequent tectonic movement from the Archaean to the Quaternary. In the Precambrian, as many as six stages of Precambrian movement have been traced. Since the Phanerozoic several transcontinental tectonic belts have developed in northern, north-western, eastern and south-western parts of China, for instance, the Palaeozoic Central Asia tectonic belt, the Mesozoic-Cenozoic circum-Pacific tectonic belt, and the MesozoicCenozoic Tethys tectonic belt. These belts became active one after the other and were superimposed on each other, as the Precambrian land mass was mobilised and reworked. The accompanying magmatism, sedimentation and metallogenesis account for the complexity, variety and abundance of minerals in China. Five metallogenic domains have been delineated (Figure 3).

\section{The Precambrian Sino-Korean-Yangtze land mass}

This domain lies within the Precambrian land mass and is represented by the Sino-Korean and Yangtze paraplatforms which were reworked intensively by the late-tectonic magmatism and superposed by late-stage metallogenesis. Nevertheless there are still some significant Precambrian metallogenic provinces left in this domain, including $\mathrm{Fe}, \mathrm{Cu}-\mathrm{Zn}$, rare earth, $\mathrm{Sn}$, magnesite, talc, B and $\mathrm{U}$ deposits. In some localities it is buried at great depth and the deepseated parts were reworked as part of the crust, making a great impact on the later ore formation. Sedimentary basins containing oil, gas, coal, $\mathrm{Fe}$ and $\mathrm{Sn}$, were formed at different times in some parts of the domain.

\section{The old Asia domain}

This is an east-west-trending transcontinental metallogenic domain of Caledonian-Hercynian age. Stretching eastward from central Asia, it enters Chinese territory in the Altay-Tianshan tectonic belt, runs through the Yinshan Mountain in the Inner Mongolia Autonomous Region and ends in the Yanshan Mountain in Liaoning and Hebei provinces. Various minerals, such as $\mathrm{Cu}, \mathrm{Ni}, \mathrm{Fe}, \mathrm{Pb}, \mathrm{Zn}$, $\mathrm{Ag}, \mathrm{Au}, \mathrm{Be}, \mathrm{Li}$ and gemstones occur. On the northern margin of the Yanshan old land mass this domain overlaps the first and it is also superposed by the tectono-metallogenesis of the Mesozoic circum-Pacific metallogenic domain.

\section{The Mesozoic-Cenozoic circum-Pacific domain}

The most significant in the country, this metallogenic domain covers a vast area of eastern China and half of the total territory. It includes not only ore deposits related to the Mesozoic-Cenozoic intermediate-acidic volcanic-subvolcanic rocks, such as $\mathrm{Cu}, \mathrm{Pb}$, $\mathrm{Zn}, \mathrm{Ag}, \mathrm{Au}, \mathrm{U}$, pyrite, bentonite, perlite, fluorite, alunite, pyrophyllite, kaolinite and building stones, but also granitoid-related deposits such as $\mathrm{W}, \mathrm{Sn}, \mathrm{Bi}, \mathrm{Mo}, \mathrm{Cu}, \mathrm{Pb}, \mathrm{Zn}$, $\mathrm{Ag}, \mathrm{Au}, \mathrm{Sb}, \mathrm{As}, \mathrm{Hg}, \mathrm{U}, \mathrm{Nb}, \mathrm{Ta}$ and REE. All these minerals constitute the well-known

Figure 3 The five metallogenic domains.
Nanling nonferrous, rare and rare earth metals-producing base, the east Qinling Mo- and Au-producing base and the Jiaodong Au-producing base. In addition, in some rifted zones between the old land masses such as the middle-lower reaches of the Yangtze River, there are minerals related to intermediate-basic volcanic-intrusive rocks such as $\mathrm{Fe}, \mathrm{S}, \mathrm{Cu}$, kaolinite, alunite and also granite- and daciterelated minerals such as $\mathrm{Cu}, \mathrm{Pb}, \mathrm{Zn}, \mathrm{Ag}, \mathrm{S}, \mathrm{Au}$ and kaolinite. Its tectonic-magmatic-metallogenic activities have been superposed on the first domain and the eastern part of the second one. The original tectonics, rocks and deposits have been reworked to various extent.

\section{The Tethys domain}

As a transcontinental domain, this forms an arc in Yunnan, Sichuan, Qinghai and Tibet of south-west China. Ore-forming processes operated from the Indosinian through the Yanshanian to the Himalayan, and were especially intensive during the Himalayan, resulting in the occurrence of deposits of $\mathrm{Cr}, \mathrm{Fe}, \mathrm{Cu}, \mathrm{Pb}, \mathrm{Zn}, \mathrm{Sn}, \mathrm{Ag}, \mathrm{Au}, \mathrm{Hg}, \mathrm{K}, \mathrm{Li}$, $\mathrm{B}$, rare earths and rock salt. It joins the third domain in Yunnan.

\section{The Qinling-Qilianshan-Kunlunshan domain}

Trending nearly east-west, this domain traverses the central part of China, a region which has experienced constant tectonic-magmatic-sedimentary-metallogenic processes between the southern and northern old land masses, with its eastern sector joining the third domain and the western sector joining the fourth one. Discoveries include $\mathrm{Cu}, \mathrm{Ni}, \mathrm{Pb}, \mathrm{Zn}, \mathrm{Au}, \mathrm{Ag}, \mathrm{Mo}, \mathrm{Sb}, \mathrm{Hg}$, gemstones, jade, kyanite, andalusite and asbestos. There is great mineral potential in the little-explored middle and western sectors.

\section{Metallogenesis through time}

According to statistics on 19 major metallogenic provinces and belts, there were three ore-forming peaks from the Archaean to the Cenozoic, i.e. the Proterozoic, the Hercynian and the Yanshanian, with the last one being the most intensive. The ore-forming highs and lows occurred alternately, and were interrelated. For example, the metallogenic low, in the tectonic cycles of the Archaean, Caledonian and Indosinian, played a significant role in the enrichment of oreforming materials for the following metallogenic high. It is concluded that ore formation in the Archaean and the Proterozoic was characterised by the enrichment of siderophile elements such as $\mathrm{Fe}$, $\mathrm{Cu}, \mathrm{Ni}, \mathrm{Co}$ and $\mathrm{Pt}$ as well as minerals such as $\mathrm{Au}, \mathrm{Ag}, \mathrm{Pb}, \mathrm{Zn}, \mathrm{REE}$, $\mathrm{Nb}, \mathrm{B}$, magnesite, talc and graphite. The Caledonian and the Hercynian were represented by deposits of $\mathrm{Cr}, \mathrm{Fe}, \mathrm{Cu}, \mathrm{Ni}, \mathrm{Pb}, \mathrm{Zn}, \mathrm{Au}$, 
Sn, Li, S, asbestos, diamond, gem and jade. The Indosinian-Yanshanian-Himalayan was dominated by the occurrence of granitoidrelated minerals, including $\mathrm{W}, \mathrm{Sn}, \mathrm{Bi}, \mathrm{Mo}, \mathrm{Sb}, \mathrm{As}, \mathrm{Ag}, \mathrm{Au}, \mathrm{Hg}, \mathrm{Cu}$, $\mathrm{Pb}, \mathrm{Zn}, \mathrm{Nb}, \mathrm{Ta}, \mathrm{REE}, \mathrm{S}$, fluorite, kaolin, perlite, pyrophyllite and building stone. So, endogenic ore formation evolved from mantlederived to crust-derived deposits and increased constantly. This common feature is consistent with the evolutionary trend of global mineralisation.

As for sedimentary deposits, they have the following characteristics at the time of formation. The Archaean and the Proterozoic saw the development of $\mathrm{Fe}$ deposits of volcano-sedimentary ferrisiliceous formation. Phosphorite deposits occurred mainly in the Sinian-Cambrian. Fe deposits occurred in the Devonian. The Carboniferous-Permian were dominated by the formation of bauxite and fireclay in large quantities. And the Cenozoic experienced the development of salt lake, B, Li, halite, mirabilite, gypsum, oil and gas.

\section{Ore-forming characteristics in provinces and belts}

Owing to the differences in their geological settings, the metallogenic provinces and belts in China bear ore-forming characteristics of their own which may be classified as the follows.

1 Metallogenic belts occurring in geosynclinal-type tectonic belts during the same geological period. This type of belt is represented by the Qilian Caledonian tectonic belt and the Altay Hercynian tectonic belt. $\mathrm{Cu}, \mathrm{Pb}, \mathrm{Zn}, \mathrm{S}$ and massive sulfide deposits associated with spilite-keratophyre sequences are found in the former, while in the latter, there are $\mathrm{Cu}, \mathrm{Ni}, \mathrm{Pb}, \mathrm{Zn}, \mathrm{Fe}, \mathrm{Au}, \mathrm{Li}$, $\mathrm{Be}$, gem and mica deposits related to Hercynian basic-intermediate-acidic volcanic-subvolcanic rocks, late-stage granite and migmatitic granite.

2 Metallogenic provinces occurring in unreworked tectonic provinces of platform type. This type of belt is rather rare in the country, and the only case is the Yuanbaoshan-Jiuwandashan $\mathrm{Cu}, \mathrm{Ni}$ and $\mathrm{Sn}$ metallogenic province in the Precambrian Yangtze old land mass of northern Guangxi.

3 Metallogenic belts occurring in geosynclinal-type tectonic belts superimposed by multiphase tectonic-magmatic-sedimentary-metallogenic processes. This type is widely developed in China. It is exemplified by the the Qinling tectonic belt where tectono-metallogenic processes operated in the Proterozoic, the Caledonian, the Hercynian and the Indosinian-Yanshanian respectively leading to metallogenic belts carrying various elements and minerals such as $\mathrm{Au}-\mathrm{Ag}-\mathrm{Ni}-\mathrm{Cu}, \mathrm{Fe}-\mathrm{Cu}-\mathrm{Pb}-\mathrm{Zn}$, $\mathrm{Pb}-\mathrm{Zn}-\mathrm{Au}-\mathrm{Ag}-\mathrm{Mo}-\mathrm{Sb}-\mathrm{Hg}$, asbestos, kyanite and graphite. Those developed in the Jinshajing-Lancangjiang-Nujiang, the Kunlun-Altun and the northern margin of the north China block tectonic belts are of the same type.

4 Metallogenic provinces occurring in tectonic provinces of platform type superposed by multiphase tectonic-magmatic-sedimentary-metallogenic processes. This type is very typical in China. For instance, the Sino-Korean paraplatform, formed in the Proterozoic, was superposed by tectonic-ore-forming processes of the Caledonian, Hercynian and Yanshanian. Such belts contain ore associations (metallogenic series) from each period, including $\mathrm{Fe}, \mathrm{Cu}, \mathrm{Zn}$ and $\mathrm{Au}$ of the Archaean, $\mathrm{Fe}, \mathrm{Cu}, \mathrm{Ni}, \mathrm{Co}$, $\mathrm{Nb}, \mathrm{REE}, \mathrm{B}, \mathrm{U}, \mathrm{Pb}$ and $\mathrm{Zn}$ of the Proterozoic, diamond of the Caledonian, $\mathrm{Cr}, \mathrm{Ni}, \mathrm{Co}, \mathrm{Fe}, \mathrm{Cu}, \mathrm{Mo}, \mathrm{Pb}, \mathrm{Zn}$ and $\mathrm{Au}$ of the Hercynian, and $\mathrm{Fe}, \mathrm{Co}, \mathrm{Cu}, \mathrm{Mo}, \mathrm{Pb}, \mathrm{Zn}, \mathrm{Au}, \mathrm{Ag}$ and kaolin of the Yanshanian. Similar cases are found in the Yangtze paraplatform of southern China.

5 Metallogenic provinces or belts occurring in intensively mobilised areas. This type is exemplified by the MesozoicCenozoic tectono-volcanic belt on the continental margin of south-east China, in which there are ore belts containing $\mathrm{Cu}, \mathrm{Pb}$, $\mathrm{Zn}, \mathrm{Au}, \mathrm{Ag}, \mathrm{W}, \mathrm{Sn}$, corundum, alunite, pyrophyllite, and kaolinite. It also fits the cases in the middle-lower reaches of the Yangtze River and the Nanling area.
Along with the tectono-magmatic features, each category of province and belt exhibits common features of migration of metallogenesis in space, and the compositions of their ore-forming elements evolved in line with a general trend for the whole country.

Some ore-forming elements are distinctively regionalised in China. For instance, over long geological periods, Au has been an active ore-forming element in the Sino-Korean paraplatform. Sn, W and $\mathrm{Sb}$ have been the ore-forming elements for the Yangtze paraplatform and the south China folded belt since the Proterozoic. The eastern sector of the Qinling Mountains has been rich in Mo and poor in $\mathrm{Cu}$. All these facts may imply that in certain parts of China, anomalous amounts of some ore-forming elements may reflect inhomogeneity in the distribution of these elements in the lithosphere.

\section{References}

Chen, Yuchuan, Pei Rongfu, et. al., 1989. The geology of nonferrous and rare metals related with the Mesozoic granitoid in the Nanling Region: Geological Publishing House.

Cheng, Yuqi. Chen, Yuchuan, Zhao, Yiming and Song, Tianrui, 1983, Further discussion on the problems of minerogenetic series of mineral deposits: Bulletin of the Chinese Academy of Geological Sciences, no. 6.

Guo, Wenkui, 1987, Metallogenic map of endogenic ore deposits of China, 1:4000 000: Cartographic Publishing House.

Mineral Resources of China, 1993, Edited by Chinese Institute of Geology and Mineral Resources Information: China Building Materials Industrial Press.

Tao, Weiping, 1988, Some regularities of the formation and distribution of the nonmetallic deposits of China-nonmetallic deposits and plate tectonics: Acta Geologia Sinica, vol. 62, no. 2 .

Tao, Weiping, 1989. The minerogenetic series of nonmetallic mineral deposits of China: Acta Geologia Sinica, vol. 63, no. 4.

Ye, Qingtong et al., 1991, The metallogenic characteristics and series of $\mathrm{Pb}$ $\mathrm{Zn}$ deposits in the Nujiang-Lancangjiang-Jinshajiang region: Beijing Science and Technology Press.

Zhai, Yusheng et al., 1992, Metallogenic regularities of $\mathrm{Fe}-\mathrm{Cu}(\mathrm{Ag})$ deposits in the middle-lower reaches of the Yangtze River: Geological Publishing House.

Yuchuan Chen is an economic geologist and Research Fellow of the Chinese Academy of Geological Sciences. He graduated from Donetsk Polytechnical Institute, Ukraine, former USSR in 1959. He has long been engaged in the study of mineral deposits, geochemistry, regional metallogeny and metallogenic prognosis. He is now President of the Chinese Academy of Geological Sciences.

Weiping Tao is a senior geologist and Vice-chief Engineer of the China National Building Materials Industrial Geology Centre, Beijing. He has long been engaged in the research of nonmetallic mineral deposits and economic geology.
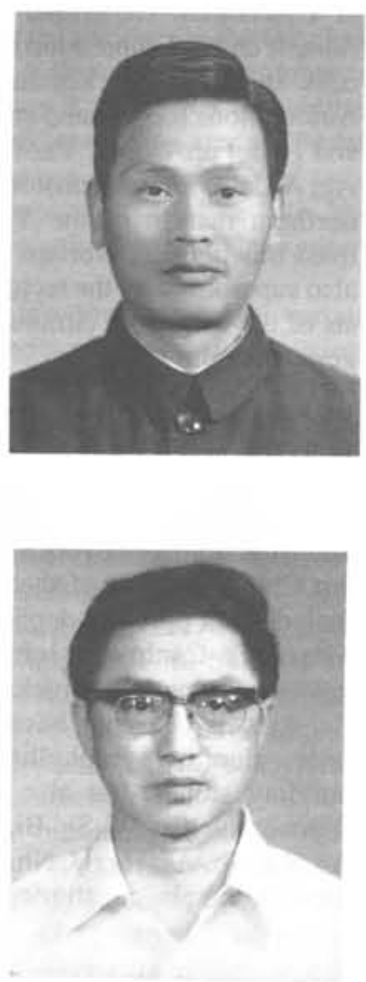